Envi r onment al di scl osure i n Japanese wood- r el at ed compani es for 2005 and 2010

\begin{tabular}{|l|l|}
\hline 著者 & Kohsaka Ryo, Tachi bana Sat oshi, I wat a Nar i \\
\hline $\begin{array}{l}\text { j our nal or } \\
\text { publ i cat i on t i t l e }\end{array}$ & I nt egr at i ve Obser vat i ons and Assessment s \\
\hline number & 21 \\
\hline page $r$ ange & 393 \\
\hline year & 2014 01-01 \\
\hline URL & ht t p: //hdl . handl e. net /2297/43125 \\
\hline
\end{tabular}




\section{Environmental disclosure in Japanese wood-related companies for 2005 and 2010}

Ryo Kohsaka, Satoshi Tachibana, Mari Iwata

R. Kohsaka

Kanazawa University, Graduate School of Human and Socio- Environmental Studies

Kakumacho, Kanzawa, Ishikawa 920-1192, Japan

S. Tachibana

University of Tsukuba, Tennodai 1-1-1, Tsukuba, Ibaraki 305-8572, Japan

M. Iwata

Mitsubishi Research Institute, Nagata-cho 2-10-3, Chiyoda-ku, Tokyo 100-8141, Japan

Present address:

R.Kohsaka

Kanazawa University, Graduate School of Human and Socio- Environmental Studies

Kakumacho, Kanzawa, Ishikawa 920-1192, Japan

Running head: Information disclosure of Japanese environmental sensitive sectors

Corresponding author: Ryo Kohsaka, kohsaka.seminar@gmail.com 


\section{Abstract}

Environmental and sustainability reports by private sectors are primarily aimed at information disclosure for individual entities. Comparison of such reports in two different years, provide us with unique opportunity to explore underpinning changes. This article compares Japanese wood-related sectors in 2005 and in 2010. During this half-decade, the economy was sluggish, with a number of dramatic meltdowns symbolized by the "Lehman shock" in 2008. The period also experience upheaval of environmental movements with a major UN COP on biodiversity taking place in Nagoya in 2010, making comparison of these two years more interesting. Environmental disclosure from 51 companies mainly from 7 wood related sectors was reviewed. The trends in disclosed information was reviewed based on the following criteria: publishing of environmental reports, reference to illegal logging, definition of sustainable forest management, and membership to the Global Compact. The results indicated an increase in many of the indicators for large size companies, particularly for trading companies, while the majority of small and mid-size companies did not conduct basic activities such as publishing reports.

Keywords: environmental report, wood-related sector, illegal logging, SFM, Forest 
certification scheme, Global Compact

\section{Introduction}

Since the 1990s, Japan has been experiencing a transitional period of corporate accountability stemming from expanding public concerns and actions toward serious global environmental issues. One of the issues is loss of biodiversity, which has captured significant public attention since the Kyushu-Okinawa G8 Summit in 2000 (Tsuru et al. 2005) and more recently the 10th Conference of the Parties to the Convention on Biological Diversity held in Nagoya, Japan, in 2010.

Forests, rainforests in particular, are critical for the health of biodiversity and increasingly important as sinks of carbon sequestration. Yet, measures to conserve and fight losses have been difficult. Illegal logging and related underground activities are identified as one of the key drivers for the loss of biodiversity. Under poor governance, illegal logging takes place in highly valuable forest areas (Navarrete et al. 2011). The government and institutional failures such as corruption and weak enforcement capacity are one of the major causes of illegal logging. Political actions and policy measures such as rules or treaties are needed, but only belatedly and insufficiently introduced (Smith et al. 2003, Palmer 2001). 
On the other hand, the private sector is arguably the most influential actor in activities related to biodiversity conservation. The behavior of private companies change due to pressure from civil societies including protests, media campaign and boycotts in extreme cases. The change in the behavior of private companies can be traced by the degree of their information disclosure, since information disclosure is a prerequisite to build trust with society. The publication of environmental or Corporate Social Responsibility (CSR) reports by companies is a method through which corporations demonstrate their accountability. In addition, environmental labeling on their products can serve a similar function.

These two aspects of reporting and certified wood products are examined here to clarify the extent and development of disclosure trends in Japanese wood-related sectors. In this study, we reviewed and analyzed CSR or Environmental reports published in 2005 and 2010 by major companies in our focus area. There were notable changes in the international policy environment from 2005 to 2010, such as revision of the Lacey Act in the United States in 2008 and implementation of Voluntary Partnership Agreements (VPA) between the EU and some developing countries. The 10th Conference of the Parties to the Convention on Biological Diversity, held in Japan in 2010, provided a major driver for the Japanese private sector to reflect and initiate their information 
disclosure and their influences related to biodiversity, mainly through supply chains.

The global economic environment also changed remarkably due to deregulation leading to the collapse of Lehman Brothers in 2008. These changes provide the rational for comparing the environmental disclosure trends of Japanese companies in 2005 and 2010.

In this survey, we assessed environmental disclosure from 51 companies from 7 wood related sectors. Wood-related sectors are those directly related to forestry, including forestry, pulp and paper, trading of wood products, supplying office equipment using wood, stationary, retail of wood products, and the housing sector. The companies from wood-related sectors are mostly small and mid-sized companies (SMEs). In addition, 4 companies from two other sectors, automobile and utility, were assessed as “non-wood related sectors”. All the companies reviewed are based in Japan. Furthermore, we included telephone and e-mail surveys for some companies and, additionally, website information into the review and analysis.

\section{Review}

1. Debate over CSR and Sustainable Development

Scientists are struggling with the question of CSR. To date, there has not been any 
internally agreed definition of the term CSR (Taneja et al. 2011). There are regional differences as well. CSR has been discussed mainly by scholars examining North American issues while "European interest in CSR is a relatively recent phenomenon" (Falck \& Heblich 2007: 248). Loew et al. (2004) made a similar observation and noted that the CSR discussion mainly focused on the United States and that similar discussions in the European context were largely associated with 'sustainable development'. From an application perspective the two concepts have been approaching each other since the 1990s with CSR increasingly being recognized as a part of sustainable development (Loew et al. 2004). In other words, there is a progressive transition towards the private sector as being part of the problems as well as part of the solutions, with CSR activities contributing towards the realization of sustainable development.

What exactly is the social responsibility of a corporation in concrete terms? There are various codes and standards for the CSR-related corporate activities. Illustrative codes and standards are shown in figure 1, including various codes, standards and legal instruments in socio-ethical, environment, and financial realms, showing at which phases the activities are checked. The phases are whether or not the companies are covering the activities at levels of policy, accounting, assurance or reporting. For 
example, ISO14001 series focuses mostly on environmental phases but does not cover any of the social or financial realms. The Global Compact is more wide ranging and covers social and ethical matters but focuses on the policy realm. This paper focuses on corporate activities at the reporting phase.

\#Fig. 1\#

2. Studies in wood-related sectors

Literature specifically for wood-related sectors is reviewed here. In general, wood-related sectors are categorized as 'environmentally sensitive industries' and it was suggested in the context of the UK and USA that these companies are more likely to increase disclosure of environmental information than companies in other sectors (Aerts et al. 2008: 645). Sectors in the same categories are oil and gas, chemicals and utilities and they are often subject to stricter governmental regulations and increased public pressure than are wood-related sectors.

The question of whether or not wood-related sectors are more willing to disclose environmental information than other sectors is addressed in two parts. First, findings from the existing studies are examined from the perspectives below. Second, the 
Japanese wood and forestry related companies and other related sectors are examined from perspectives of environmental reporting. Relevant studies are reviewed according to the study area, variables (or measurable points) and any characteristics examined (Table 1).

\#Table 1\#

Studies specific to the paper and pulp industry exist (Mikkilä et al. 2005; Mikkilä \& Toppinen 2008). Mikkilä et al. (2005) analyzed four sawmills in China, Finland, Germany and Portugal and looked at specified trends in their social performance. Reports by the world's largest Japanese, North American and Scandinavian pulp and paper companies “shows little regional variation” (Mikkilä \& Toppinen 2008: 505). These results were found true despite an orientation toward profit-making (Japan), philanthropy (North America) and compliance (Scandinavian) as pointed out in the existing literature.

Kärnä et al. (2003) suggest that the value chain closest to end-users emphasizes both "redirecting towards sustainability" and "profitability orientation" in their values more than companies at the beginning of the chain. This suggests that the environmental 
activities in the sector are reactions to consumer and other stakeholder responses.

Vidal \& Kozak (2008) reviewed the top 20 paper and pulp companies using a content analysis methodology. They compared the trends and content of the environmental reports in 2000 and 2005. For example, they demonstrated that ‘sustainable forestry’ was one of the most well-covered topics in both 2000 and 2005. Economics, human resources, and certification related elements are amongst the topics that increased in coverage from 2000 to 2005.

Kärnä et al. (2001) investigated the substance behind the green advertisement of the Finnish forestry sector by checking environmental activities at various phases of the supply chain (decision making, recruitment, planning, etc.) to see whether activities in the advertisements are implemented on the ground. They found that "there is clear environmental substance” (Kärnä et al. 2001) and that it is not mere green advertisement, but practices are in place.

It should, however, be noted that the Finnish forestry sector is not SMEs but mostly large companies. In Japan, SMEs are an important factor as the majority of companies in the Japanese forestry sector consist of this category. This provides us with a unique opportunity to explore the disclosure activities and notion of CSR. Existing studies indicate that the external pressures from stakeholders, including those of civil 
societies and foreign capitals are the drivers for CSR activities (Lynch-Wood et al. 2009,

Oh et al. 2011). The pressures from neighborhoods, environmental groups, community

members or foreign capitals can actually positively affect the behavior of the

corporation to act in a more socially responsible manner. On the other hand, these

pressures are unlikely to motivate the SMEs as the potential influences to their

reputations and their stakeholders would be less significant (Lynch-Wood et al. 2009).

Thus, there is a need to capture the factors and possible motivations for CSR

initiatives with specific conditions for SMEs.

\section{Analysis and results}

\section{Overview}

A review of CSR or Environmental reports was conducted on 55 companies from 9 sectors. The first aspect of the analysis focused on whether the selected companies disclose information in the form of CSR or environmental reports. Second, by comparing 2005 and 2010 reports with other related sources of information, references to illegal logging and their changes over time were examined. Illegal logging harvesting timber in contravention of a country's laws - and the associated trade of wood and wood products are worldwide problems that have widespread economic and 
environmental impacts (FFPRI 2005). Finally, the trend towards the use of certified wood products was assessed. Forest certification schemes have an important role in realizing sustainable forest management (SFM). The results are summarized in the table below (Table 2). In addition, basic information on the reviewed companies is also provided (Table 3). Because, three companies had not published a 2010 report when we conducted our survey, the 2009 reports were used instead.

\#Table 2\#

\#Table 3\#

We found that the majority of companies in the forestry sector (mostly wood handling and processing companies) had not published any CSR or Environmental reports in 2005 and in 2010. The size of these companies and the scale of their budgets probably had the most influence on whether a company was disclosing environment-related information or not. The amount of capital in the forestry sector is low compared to that in other sectors.

Since few companies in the forestry sectors published CSR or Environmental 
reports, surveys were conducted by the telephone and e-mail. There are several trends in the wood-related sectors between 2005 and 2010, with the major trends summarized as follows:

- A continued lack of or limited disclosure of environmental information from companies in the Japanese wood-related sectors (two companies in the 2005 reports and one in 2010 out of 18 companies).

- A shift towards providing certified products (from one company in 2005 to nine in 2010 out of 18 companies).

- A major increase in references to illegal logging, especially for wood, paper and pulp, and trading companies (from one in 2005 to all 18 companies in the sectors, if we include references to supply chain and certified products to combat illegal logging).

Out of 18 companies, the reference to and provision of certified products were limited to only one company in 2005 but half of the companies were providing certified products by 2010. There were more options for the third party certification in the wood-related sectors in 2010 than in 2005. The certificate scheme includes forest management certification and chain of custody certification. 
References to illegal logging issues are now common and the frequency of

references increased during the 5-year period. In Japan, the Ministry of Environment revised the "Law Concerning the Promotion of Procurement of Eco-Friendly Goods and Services by the State and Other Entities” (known as “the Law on Promoting Green Purchasing”) in 2006 introducing guidelines for procuring legal wood and wood products. Under the guidelines, many industrial associations in the wood-related sectors have been registered as certifier since 2006, certifying companies supplying eco-friendly goods. Few companies made references to illegal logging issues in 2005, but the issue became more prevalent in 2010 and all companies in wood-related sectors made some references or activities to prevent illegal logging. The key components of CSR or Environmental reports in reference to illegal logging issues and certification actions for SFM are reviewed individually below.

2. CSR or Environmental reports

Table 4 shows the summary of the reporting in 2005 and 2010.

\#Table 4\# 
Trends are clearly specific to each sector. In the forestry and stationary sectors, it is not common to publish CSR or Environmental reports. In the sectors with large companies, the majority of companies published reports both in 2005 and 2010. Since most of the companies in the wood-related sector are small to medium size, they did not publish report in 2005. The situation remained the same in 2010; one company published a report in 2005 but could not be confirmed for 2010 .

In general, companies operating in the wood-related sectors were less forthcoming to disclose information compared to other industries. When interviewed by telephone for illegal logging and SFM, especially small to med sized companies, were cautious. The so-called "Sick House Syndrome" (sickness caused by air pollutants in newly built houses) was one of the major issues in the media around 2005 and the companies were very sensitive about the issue when interviewed (this issue was not a focus of our study).

Some staff members of the forest or housing-related companies were nervous and so did not communicate clearly. They responded that their products did not contain any chemical elements related to the sickness even though the question was on other topics such as SFM. 


\section{Reference to Illegal Logging}

While the publication of CSR or Environmental reports has made little progress in some areas, references to illegal logging have significantly increased over the last 5 years (Table 5). Since not all the companies publish their CSR or Environmental reports, we confirmed the references in the following way:

1) If the company published a report, we examined whether or not some references to illegal logging issues are made in the reports.

2) If the company does not publish a report, we looked at their website and reviewed the related materials published online.

3) In addition to the website, we examined if companies have obtained a certificate as a “legal woods supplier” issued by a wood industry association. We assumed that taking such a certificate indicated awareness of the impact of illegal logging and that they are willing to take action to prevent it (Table 5).

\#Table 5\#

In the wood-related sectors, only one company referred to illegal logging issues in 
2005. That company obtained an FSC Forest Management (FM) certificate in 2005. In 2010, all the companies surveyed had been certified as suppliers of legal wood products by a wood industry association. Normally such certificates were only available after 2006 under the revised “Law on Promoting Green Purchasing”. Also an increasing number of companies had obtained FSC FM and other sustainability certificates in 2010. In the pulp and paper sector, we observed changes between 2005 and 2010. These companies were making more frequent references to illegal logging in 2010 than in 2005. In 2010, companies took some actions such as using certified wood products as raw materials, and embedding "legality” into their procurement policies. Similar trends were identified for trading companies. While the reference to "illegal logging” issues in the reports has become a new norm for the paper and pulp and trading sectors, it is less common among the stationary, retail and housing sectors over the same survey period.

\section{Certification for Sustainable Forest Management}

The trend of certified wood products was assessed in Table 6.

\#Table 6\# 
The number of certified wood products increased remarkably in product lineups of wood-related companies. Larger scale companies are especially obtaining FSC and/or PEFC certificates. Most of them obtained the certificates in the year 2010, but early ones started in 2006 or 2009. The companies indicated that the driving force for obtaining certification is demand from the customers for more environmentally friendly products or questions regarding the risk of their products containing illegally logged wood. These customer questions were channeled through the branches to company headquarters, leading to changes in their products in many cases. In the case of one company, the PEFC certified products were introduced in response to the concern of customers against illegally logged woods, but they also mentioned that the customers are not willing to pay a higher price.

One small or medium-sized company indicated why they have not yet introduced forest certified products. First, the cost of obtaining such a certificate is yet to be reflected in product prices. In other words, “there are needs for certified products but the products are not yet pricing in the costs.” The other reason for not obtaining certification is that the area of forest that is owned is not large enough to warrant paying the costs for certification. 


\section{Summary}

A significant increase in references to illegal logging was found, especially for wood, pulp and paper, and trading companies. Those sectors also started to provide certified products. What was the driving force behind these changes? There were government policy reasons for these changes in 2010. The Ministry of Land, Infrastructure, Transport and Tourism (MLIT) started a program to support "Long-Life Quality Housing” by providing a 200,000 Yen/house subsidy, if legal timber locally harvested is used for construction. Furthermore, as the Japanese "Law on Promotion of Use of Wood in Public Buildings” is enforced, public buildings will shift towards using more sustainable wood products. In addition to these policy changes, several companies responded that their customers are requesting certified products (even though they might not be ready to pay more).

These two elements are estimated to be the underlying forces for the changes between 2005 and 2010. In general, the companies in wood-related sectors are making more frequent reference to illegal logging issues in 2010 than in 2005 and are providing more certified products such as FSC, PEFC, SGEC and legal wood products. Yet, not all trends were positive. The number of companies publishing environmental or sustainability reports actually decreased. 


\section{Conclusions}

How can we change the behavior of the private sector? Scientific projects to

evaluate ecosystem services in quantitative terms are underway. In this volume with other authors, the visualization of ecological footprints is discussed. Such quantification and mapping measures are important tools for the future, but probably not rigorous enough for monitoring purposes. In this paper we have examined the changes in information disclosure of the private sector in 2005 and 2010. This practical review is an important source to actually monitor the changes of the private sector.

Firstly we reviewed the existing literature in forestry science and found some evidence indicated that the wood-related sectors are disclosing substantial information and it is not a mere advertisement, such as in the case of the Finnish forest industry. The need to explore SMEs in a quantitative manner, instead of case studies was identified as area to be explored.

Secondly we reviewed reporting by companies in the Japanese wood-related sectors. We found that the majority of the companies in the Japanese wood-related sectors were publishing environmental reports less frequently than in other sectors. The size of the company and the scale of their budget probably had more influence on 
whether a company was disclosing more environment related information or not. Our work confirms the findings from Lynch-Wood et al. (2009) that SMEs have different motivations than large-sized companies do.

We found an important factor of more exposures to overseas consumers and partners were critical in companies disclosing information and joining CSR initiatives. The latter result was especially apparent for sectors such as paper and pulp or trading sectors with involvement with certified products or memberships with the Global Compact.

Further research is necessary to see what could potentially motivate Japanese wood-related sectors to disclose more information. The sectors do not have much exposure to foreign partners and will need different types of drivers and pressure to disclose more information.

\section{References}

Aerts W., Cormier, D. Magnan, M. (2008) Corporate Environmental Dislcosure, Financial Markets and the Media: An International Perspective. Ecological Economics. 64: 643-659.

Falck, O., Heblich, S. (2007) Corporate Social Responsibility: Doing Well by Doing 
Good. Business Horizons. 50:247-254.

Forestry and Forest Products Research Institute (FFPRI) (2005) Current Activities to Combat Illegal Logging and Associated Trade in Illegally Sourced Wood Products in Japan. Prepared for DFID, 54pp. Accessed 25 Sep 2011. http://www.illegal-logging.info/uploads/Japan_illegal_logging_action_survey_ 2005[1].pdf

Kärnä J., Juslin H., Ahonen, V. and Hansen E. (2001) Green Advertising: Greenwash or a True Reflection of Marketing Strategy? Greener Management International: 33-59-70.

Kärnä J., Hansen E., Juslin H. (2003) Social Responsibility in Environmental Marketing Planning. European Journal of Marketing 37:848-871.

Loew T., Ankele, K., Braun, S., Clausen, J. (2004) Bedeutung der CSR-Diskussion für Nachhaltigkeit und die Anforderungen an Unternehmen (Significance of the CSR Debate for Sustainability and the Requirements for Companies), IÖW, $126 p p$.

Lynch-Wood, G., Williamson D., \& Jenkins, W. (2009) The Over-reliance on Self-regulation in CSR Policy. Business Ethics. 18:52-65.

Mikkilä, M. Kolehmainen, O., Pukkala, T. (2005) Multi-attribute Assessment of 
Acceptability of Operations in the Pulp and Paper Industries. Forest Policy and Economics. 7:227-243.

Mikkilä, M., Toppinen A. (2008) Corporate Responsibility Reporting by Large Pulp and Paper Company. Forest Policy and Economics. 10:500-506.

Navarrete, J., Ramirez, M.,Perez-Salicrup, D. (2011) Logging within Protected Areas: Special Evaluation of the Monarch Butterfly Biosphere Reserve, Mexico. Forest Ecology and Management. 262:646-654.

Oh, W., Chang, Y., Martynov, A. (2011 in press) The Effect of Ownership Structure on Corporate Social Responsibility: Empirical Evidence from Korea. Journal of Business Ethics doi: 10.1007/s10551-011-0912-z

Palmer. C. (2001) The Extent and Causes of Illegal Logging: an Analysis of a Major Cause of Tropical Deforestation in Indonesia. Center of Social and Economic Research on the Global Environment Working Paper.

Smith. J, Obidzinski. K, Subarudi. Suramenggala.I, (2003) Illegal Logging, Collusive Corruption and Fragmented Governments in Kalimantan, Indonesia. International Forestry Review. 5(3): 293-302.

Taneja S, Taneja, P., Gutpa. R, (2011) Researches in Corporate Social Responsibility: A Review of Shifting Focus, Paradigms, and Methodologies. Journal of Business 
Ethics. 101:343-364

Tsuru S. et al (2005) Current Activities to Combat Illegal Logging and Associated Trade in Illegally Sourced Wood Products in Japan. Prepared for DFID, UK, Forestry \& Forest Products Research Institute.

Vidal, N.G., Kozak, R.A. (2008) The Recent Evolution of Corporate Responsibility Practices in the Forestry Sector. International Forestry Review. 10: 1-13. 


\section{Table Captions}

Table 1. Review of major existing literature in forestry science.

Trend of each sectors performance on CSR activities and sustainable forestry (comparison between 2005 and 2010).

Table 3. Review results on a company basis.

Table 4. The number of companies publishing CSR or Environmental reports in 2005/2010.

Table 5. The number of companies referring to illegal logging issues in 2005/2010.

Table 6. The number of companies getting Sustainable Forest Management certificate or retailing certified products in 2005/2010. 
Fig.1 Range of CSR related standards and criteria.

Original: Humboldt-Universität zu Berlin / Institut für Management "Standards, Codes of Conduct und Berichterstattung” Revised by the authors 
Table 1. Review of major existing literature in forestry science.

\begin{tabular}{|c|c|c|c|}
\hline Author & Study Area & Variables/Measure & Characteristics \\
\hline $\begin{array}{l}\text { Kärnä et al. } \\
\text { (2001) }\end{array}$ & $\begin{array}{l}\text { Finnish forest } \\
\text { industry }\end{array}$ & & \\
\hline Mikkilä et al. (2005) & $\begin{array}{l}\text { Pulp and Paper: } \\
\text { China, Finland, } \\
\text { Germany and } \\
\text { Portugal } \\
\end{array}$ & $\begin{array}{l}\text { economic, legal, } \\
\text { ethical and } \\
\text { discretionary } \\
\text { responsibility } \\
\end{array}$ & Social performance \\
\hline $\begin{array}{l}\text { Mikkilä and } \\
\text { Toppinen (2008) }\end{array}$ & $\begin{array}{l}\text { World Largest } 10 \\
\text { Pulp and Paper (US } \\
\text { Finland, Sweden, } \\
\text { Japan) }\end{array}$ & $\begin{array}{l}\text { Merits for } \\
\text { sustainability } \\
\text { performance } \\
\text { (Economic, } \\
\text { Environmental, } \\
\text { Social) }\end{array}$ & $\begin{array}{l}\text { Focus on pulp and } \\
\text { paper }\end{array}$ \\
\hline $\begin{array}{l}\text { Vidal \& Kozak } \\
\text { (2008) }\end{array}$ & $\begin{array}{l}\text { World Largest } 20 \\
\text { Pulp and Paper } \\
\text { companies }\end{array}$ & $\begin{array}{l}\text { content analysis } \\
\text { methodology } \\
\text { Environmental reports } \\
\text { (i) Nr. Pages (ii) type } \\
\text { of reports (iii) topics }\end{array}$ & $\begin{array}{l}\text { Focus on pulp and } \\
\text { paper period } \\
2000-2005\end{array}$ \\
\hline
\end{tabular}

* Compiled by the author modifying Table 1 of Mikkilä and Toppinen, 2008. 
Table 2. Trend of each sectors performance on CSR activities and sustainable forestry (comparison between 2005 and 2010).

\begin{tabular}{|c|c|c|c|c|}
\hline Sector & $\begin{array}{c}\text { CSR/Environme } \\
\text { ntal reporting }\end{array}$ & $\begin{array}{l}\text { Reference to } \\
\text { illegal logging }\end{array}$ & $\begin{array}{c}\text { Sustainable } \\
\text { forest } \\
\text { management }\end{array}$ & Global compact \\
\hline Forestry & $\downarrow_{2 / 18 \rightarrow 1 / 18}$ & $\underset{1 / 18 \rightarrow 18 / 18}{\uparrow \uparrow}$ & $\uparrow_{1 / 18 \rightarrow 9 / 18}$ & $\begin{array}{c}\longrightarrow \\
0 / 18 \rightarrow 0 / 18\end{array}$ \\
\hline Pulp\&Paper & $\begin{array}{c}\longrightarrow \\
6 / 6 \rightarrow 6 / 6\end{array}$ & $\begin{array}{c}\uparrow \uparrow \\
3 / 6 \rightarrow 6 / 6\end{array}$ & $\begin{array}{c}\longrightarrow \\
6 / 6 \rightarrow 6 / 6\end{array}$ & $\begin{array}{c}\longrightarrow \\
2 / 6 \rightarrow 2 / 6\end{array}$ \\
\hline Trading & $\begin{array}{c}\longrightarrow \\
5 / 5 \rightarrow 5 / 5\end{array}$ & $\begin{array}{c}\uparrow \uparrow \\
1 / 5 \rightarrow 4 / 5\end{array}$ & $\begin{array}{c}\longrightarrow \\
5 / 5 \rightarrow 5 / 5\end{array}$ & $\begin{array}{c}\uparrow \uparrow \\
1 / 5 \rightarrow 5 / 5\end{array}$ \\
\hline $\begin{array}{l}\text { Supplying } \\
\text { office } \\
\text { equipments }\end{array}$ & $\underset{6 / 6 \rightarrow 5 / 6}{\downarrow}$ & $\underset{1 / 6 \rightarrow 4 / 6}{\uparrow}$ & $\begin{array}{c}\uparrow \uparrow \\
1 / 6 \rightarrow 5 / 6\end{array}$ & $\begin{array}{c}\uparrow \\
2 / 6 \rightarrow 4 / 6\end{array}$ \\
\hline Stationary & $\begin{array}{c}\longrightarrow \\
3 / 7 \rightarrow 3 / 7\end{array}$ & $\underset{1 / 7 \rightarrow 2 / 7}{\uparrow}$ & $\begin{array}{c}\longrightarrow \\
2 / 7 \rightarrow 2 / 7\end{array}$ & $\begin{array}{c}\longrightarrow \\
0 / 7 \rightarrow 0 / 7\end{array}$ \\
\hline Retail & $\downarrow_{4 / 4 \rightarrow 3 / 4}$ & $\underset{0 / 4 \rightarrow 1 / 4}{\uparrow}$ & $\begin{array}{c}\uparrow \\
0 / 4 \rightarrow 2 / 4\end{array}$ & $\begin{array}{c}\longrightarrow \\
0 / 4 \rightarrow 1 / 4\end{array}$ \\
\hline Housing & $\begin{array}{c}\longrightarrow \\
5 / 5 \rightarrow 5 / 5\end{array}$ & $\begin{array}{c}\uparrow \\
0 / 5 \rightarrow 2 / 5\end{array}$ & $\begin{array}{c}\uparrow \\
1 / 5 \rightarrow 3 / 5\end{array}$ & $\begin{array}{c}\uparrow \\
0 / 5 \rightarrow 3 / 5\end{array}$ \\
\hline Automobile & $\begin{array}{c}\longrightarrow \\
2 / 2 \rightarrow 2 / 2\end{array}$ & $\begin{array}{c}\longrightarrow \\
0 / 2 \rightarrow 0 / 2\end{array}$ & $\begin{array}{c}\uparrow \\
0 / 2 \rightarrow 1 / 2\end{array}$ & $\begin{array}{c}\uparrow \\
0 / 2 \rightarrow 1 / 2\end{array}$ \\
\hline Utility & $\downarrow_{2 / 2 \rightarrow 1 / 2}$ & $\begin{array}{c}\longrightarrow \\
0 / 2 \rightarrow 0 / 2\end{array}$ & $\begin{array}{c}\longrightarrow \\
0 / 2 \rightarrow 0 / 2\end{array}$ & $\begin{array}{c}\longrightarrow \\
0 / 2 \rightarrow 0 / 2\end{array}$ \\
\hline
\end{tabular}

N.B. Numbers beneath the arrow lines indicate "the number of companies who performed listed environmental activities in 2005 / (out of) the total number out of companies subject to research, and the number of companies which performed in 2010 / (out of) the total number of companies subject to research”. $\uparrow \uparrow$ is for a sector which improved their performance significantly with more than $80 \%$ of companies performing listed activities. $\uparrow$ is for a sector which improved their performance to some extent with less than $80 \%$ of companies performing listed activities. $\rightarrow$ is for a sector whose performance remained the same in 2005 and 2010. $\downarrow$ is for a sector which has less companies performing listed activities in 2010 than in 2005. 
Table 3. Review results on a company basis (1/2).

\begin{tabular}{|c|c|c|c|c|c|c|c|c|c|c|}
\hline \multicolumn{3}{|c|}{ Company } & \multicolumn{2}{|c|}{$\begin{array}{l}\text { CSR/Environme } \\
\text { ntal reporting }\end{array}$} & \multicolumn{2}{|c|}{$\begin{array}{l}\text { Reference to } \\
\text { illegal logging }\end{array}$} & \multicolumn{2}{|c|}{$\begin{array}{l}\text { Sustainable } \\
\text { forest } \\
\text { management } \\
\text { certificate }\end{array}$} & \multicolumn{2}{|c|}{ Global compact } \\
\hline No. & $\begin{array}{l}\text { Capital } \\
\text { (Million } \\
\text { JPY) }\end{array}$ & Employees & 2005 & 2010 & 2005 & 2010 & 2005 & 2010 & 2005 & 2010 \\
\hline \multicolumn{11}{|c|}{ Forestry } \\
\hline 1 & NA & 18 & Yes & No & Yes & Yes & Yes & Yes & No & No \\
\hline 2 & 100 & 1,149 & No & No & No & Yes & No & Yes & No & No \\
\hline 3 & 42 & NA & No & No & No & Yes & No & Yes & No & No \\
\hline 4 & 7,324 & 1,579 & Yes & Yes & No & Yes & No & Yes & No & No \\
\hline 5 & 100 & NA & No & No & No & Yes & No & Yes & No & No \\
\hline 6 & 9,000 & 1,016 & No & No & No & Yes & No & Yes & No & No \\
\hline 7 & 50 & NA & No & No & No & Yes & No & Yes & No & No \\
\hline 8 & 100 & 1,646 & No & No & No & Yes & No & Yes & No & No \\
\hline 9 & NA & 110 & No & No & No & Yes & No & Yes & No & No \\
\hline 10 & NA & NA & No & No & No & Yes & No & No & No & No \\
\hline 11 & 100 & 102 & No & No & No & Yes & No & No & No & No \\
\hline 12 & 403 & 427 & No & No & No & Yes & No & No & No & No \\
\hline 13 & 41 & 73 & No & No & No & Yes & No & No & No & No \\
\hline 14 & 24 & 25 & No & No & No & Yes & No & No & No & No \\
\hline 15 & 160 & 60 & No & No & No & Yes & No & No & No & No \\
\hline 16 & 52 & 93 & No & No & No & Yes & No & No & No & No \\
\hline 17 & 190 & 67 & No & No & No & Yes & No & No & No & No \\
\hline 18 & 50 & NA & No & No & No & Yes & No & No & No & No \\
\hline \multicolumn{11}{|c|}{ Pulp \& Paper } \\
\hline 1 & 103,380 & 4,021 & Yes & Yes & Yes & Yes & Yes & Yes & Yes & Yes \\
\hline 2 & 55,730 & 13,834 & Yes & Yes & Yes & Yes & Yes & Yes & Yes & Yes \\
\hline 3 & 32,756 & 4,304 & Yes & Yes & Yes & Yes & Yes & Yes & No & No \\
\hline 4 & 5,140 & 89 & Yes & Yes & No & Yes & Yes & Yes & No & No \\
\hline 5 & 42,021 & 4,023 & Yes & Yes & No & Yes & Yes & Yes & No & No \\
\hline 6 & 30,400 & 3,238 & Yes & Yes & No & Yes & Yes & Yes & No & No \\
\hline \multicolumn{11}{|c|}{ Trading } \\
\hline 1 & 202,241 & 4,358 & Yes & Yes & Yes & Yes & Yes & Yes & No & Yes \\
\hline 2 & 341,482 & 6,118 & Yes & Yes & No & Yes & Yes & Yes & Yes & Yes \\
\hline 3 & 203,598 & 5,665 & Yes & Yes & No & No & Yes & Yes & No & Yes \\
\hline 4 & 219,300 & 5,218 & Yes & Yes & No & Yes & Yes & Yes & No & Yes \\
\hline 5 & 262,686 & 4,020 & Yes & Yes & No & Yes & Yes & Yes & No & Yes \\
\hline \multicolumn{11}{|c|}{ Supplying office equipments } \\
\hline 1 & 20,000 & 9,911 & Yes & Yes & Yes & Yes & Yes & Yes & Yes & Yes \\
\hline 2 & 135,300 & 109,014 & Yes & Yes & No & Yes & No & Yes & No & Yes \\
\hline 3 & 53,240 & 13,311 & Yes & Yes & No & Yes & No & Yes & Yes & Yes \\
\hline 4 & 174,762 & 26,019 & Yes & Yes & No & Yes & No & Yes & No & Yes \\
\hline 5 & 12,000 & 13,109 & Yes & Yes & No & No & No & No & No & No \\
\hline 6 & 10,375 & 6,760 & Yes & No & No & No & No & Yes & No & No \\
\hline
\end{tabular}


Table 3. continued (2/2).

\begin{tabular}{|c|c|c|c|c|c|c|c|c|c|c|}
\hline \multicolumn{3}{|c|}{ Company } & \multicolumn{2}{|c|}{$\begin{array}{l}\text { CSR/Environme } \\
\text { ntal reporting }\end{array}$} & \multicolumn{2}{|c|}{$\begin{array}{l}\text { Reference to } \\
\text { illegal logging }\end{array}$} & \multicolumn{2}{|c|}{$\begin{array}{c}\text { Sustainable } \\
\text { forest } \\
\text { management } \\
\text { certificate } \\
\end{array}$} & \multicolumn{2}{|c|}{ Global compact } \\
\hline No. & $\begin{array}{l}\text { Capital } \\
\text { (Million } \\
\text { JPY) }\end{array}$ & Employees & 2005 & 2010 & 2005 & 2010 & 2005 & 2010 & 2005 & 2010 \\
\hline \multicolumn{11}{|c|}{ Stationary } \\
\hline 1 & 15,800 & 4,991 & Yes & Yes & Yes & Yes & Yes & Yes & No & No \\
\hline 2 & 3,535 & 469 & Yes & No & No & Yes & Yes & Yes & No & No \\
\hline 3 & 4,500 & 826 & Yes & Yes & No & No & No & No & No & No \\
\hline 4 & 90 & 972 & Yes & Yes & No & No & No & No & No & No \\
\hline 5 & 200 & 394 & No & No & No & No & No & No & No & No \\
\hline 6 & 2,341 & 1,181 & No & No & No & No & No & No & No & No \\
\hline 7 & 4,497 & 551 & No & No & No & No & No & No & No & No \\
\hline \multicolumn{11}{|c|}{ Retail } \\
\hline 1 & 199,054 & NA & Yes & Yes & No & No & No & Yes & No & Yes \\
\hline 2 & 100 & 17,026 & Yes & No & No & No & No & No & No & No \\
\hline 3 & 58,566 & 5,706 & Yes & Yes & No & No & No & No & No & No \\
\hline 4 & 17,200 & 5,729 & Yes & Yes & No & Yes & No & Yes & No & No \\
\hline \multicolumn{11}{|c|}{ Housing } \\
\hline 1 & $1,101,205$ & 13,482 & Yes & Yes & No & No & No & Yes & No & No \\
\hline 2 & 103 & 25,085 & Yes & Yes & No & No & No & No & No & Yes \\
\hline 3 & 186,554 & 15,032 & Yes & Yes & No & Yes & No & Yes & No & No \\
\hline 4 & 100,000 & 19,770 & Yes & Yes & No & No & No & No & No & Yes \\
\hline 5 & 27,672 & 13,601 & Yes & Yes & No & Yes & Yes & Yes & No & Yes \\
\hline \multicolumn{11}{|c|}{ Automobile } \\
\hline 1 & 397,050 & 320,590 & Yes & Yes & No & No & No & Yes & No & No \\
\hline 2 & 605,813 & 29,878 & Yes & Yes & No & No & No & No & No & Yes \\
\hline \multicolumn{11}{|c|}{ Utility } \\
\hline 1 & 676,400 & 38,671 & Yes & No & No & No & No & No & No & No \\
\hline 2 & 489,300 & 22,143 & Yes & Yes & No & No & No & No & No & No \\
\hline
\end{tabular}

Note: NA in the table means not available. 
Table 4. The number of companies publishing CSR or Environmental reports in 2005/2010.

\begin{tabular}{|c|c|c|c|c|}
\hline Sector & $\begin{array}{l}\text { Total No. } \\
\text { of the } \\
\text { companies } \\
\text { reviewed }\end{array}$ & $\begin{array}{l}\text { No. of } \\
\text { companies } \\
\text { publishing } \\
\text { report in } \\
2005\end{array}$ & $\begin{array}{l}\text { No. of } \\
\text { companies } \\
\text { publishing } \\
\text { report in } \\
2010\end{array}$ & Note \\
\hline Forestry & 18 & 2 & 1 & - \\
\hline Pulp \& Paper & 6 & 6 & 6* & - \\
\hline Trading & 5 & 5 & 5 & - \\
\hline $\begin{array}{l}\text { Supplying } \\
\text { office } \\
\text { equipments }\end{array}$ & 6 & 6 & 5 & $\begin{array}{l}\text { One company started web } \\
\text { based reporting, instead of } \\
\text { printing a report. }\end{array}$ \\
\hline Stationary & 7 & 3 & $3^{*}$ & $\begin{array}{l}\text { One company started web } \\
\text { based reporting instead of } \\
\text { printing a report, another } \\
\text { one started to report. }\end{array}$ \\
\hline Retail & 4 & 4 & 3 & $\begin{array}{l}\text { One company ceased to } \\
\text { publish its report due to } \\
\text { change of business } \\
\text { circumstances (M\&A). }\end{array}$ \\
\hline Housing & 5 & 5 & 5 & \\
\hline Automobile & 2 & 2 & 2 & \\
\hline Utility & 2 & 2 & 1 & $\begin{array}{l}\text { TEPCO ceased to publish } \\
\text { its CSR report due to } \\
\text { nuclear accident (at the time } \\
\text { of writing). }\end{array}$ \\
\hline
\end{tabular}

* Two companies in the pulp\& paper industry and one company in stationary have not published their 2010 reports yet at the time of writing, so we used 2009 reports. 
Table 5. The number of companies referring to illegal logging issues in 2005/2010.

\begin{tabular}{l|c|c|c|l}
\hline Sector & $\begin{array}{c}\text { Total No. } \\
\text { of the } \\
\text { companies } \\
\text { reviewed }\end{array}$ & $\begin{array}{c}\text { No. of } \\
\text { companies } \\
\text { referring to } \\
\text { illegal } \\
\text { logging in } \\
2005\end{array}$ & $\begin{array}{c}\text { No. of } \\
\text { companies } \\
\text { referring to } \\
\text { illegal } \\
\text { logging in } \\
2010\end{array}$ & $\begin{array}{c}\text { Actions taken by companies which } \\
\text { refer to illegal logging }\end{array}$ \\
\hline Forestry & 18 & 1 & 18 & $\begin{array}{l}\text { Taking certificates for legal wood } \\
\text { supplier and for sustainable forest } \\
\text { management }\end{array}$ \\
\hline Pulp \& Paper & 6 & 3 & 6 & $\begin{array}{l}\text { Using certified wood products, } \\
\text { Making procurement rules }\end{array}$ \\
\hline Trading & 5 & 1 & 4 & $\begin{array}{l}\text { Using certified wood products, } \\
\text { Making procurement rules }\end{array}$ \\
\hline $\begin{array}{l}\text { Supplying } \\
\text { office } \\
\text { equipments }\end{array}$ & 6 & 1 & 4 & $\begin{array}{l}\text { Using certified wood products, } \\
\text { Making procurement rules, } \\
\text { Funding conservation projects }\end{array}$ \\
\hline Stationary & 7 & 1 & 2 & Making procurement rules \\
\hline Retail & 4 & 0 & 1 & Funding conservation projects \\
\hline Housing & 5 & 0 & 2 & Using certified wood products \\
\hline Automobile & 2 & 0 & 0 & - \\
\hline Utility & 2 & 0 & 0 & - \\
\hline
\end{tabular}


Table 6. The number of companies getting Sustainable Forest Management certificate or retailing certified products in 2005/2010.

\begin{tabular}{l|c|c|c|l}
\hline \multicolumn{1}{c|}{ Sector } & $\begin{array}{c}\text { Total No. } \\
\text { of the } \\
\text { companies } \\
\text { reviewed }\end{array}$ & $\begin{array}{c}\text { No. of } \\
\text { companies } \\
\text { in 2005 }\end{array}$ & $\begin{array}{c}\text { No. of } \\
\text { companies } \\
\text { in } 2010\end{array}$ & \multicolumn{1}{|}{ Note } \\
\hline Forestry & 18 & 1 & 9 & - \\
\hline Pulp \& Paper & 6 & 6 & 6 & - \\
\hline Trading & 5 & 5 & 5 & - \\
\hline $\begin{array}{l}\text { Supplying } \\
\text { office } \\
\text { equipments }\end{array}$ & 6 & 1 & 5 & Supplying FSC paper \\
\hline Stationary & 7 & 2 & 2 & - \\
\hline $\begin{array}{l}\text { Retail } \\
\text { Housing }\end{array}$ & 5 & 0 & 2 & $\begin{array}{l}\text { Supplying FSC paper, } \\
\text { Building their shop with FSC } \\
\text { wood products }\end{array}$ \\
\hline Automobile & 2 & 1 & 3 & $\begin{array}{l}\text { Supplying FSC wood products, } \\
\text { Using FSC paper in their operation } \\
\text { (such as catalog, business card, } \\
\text { etc), }\end{array}$ \\
\hline Utility & 2 & 0 & 0 & $\begin{array}{l}\text { FSC certificate in company owned } \\
\text { forest }\end{array}$ \\
\hline
\end{tabular}


